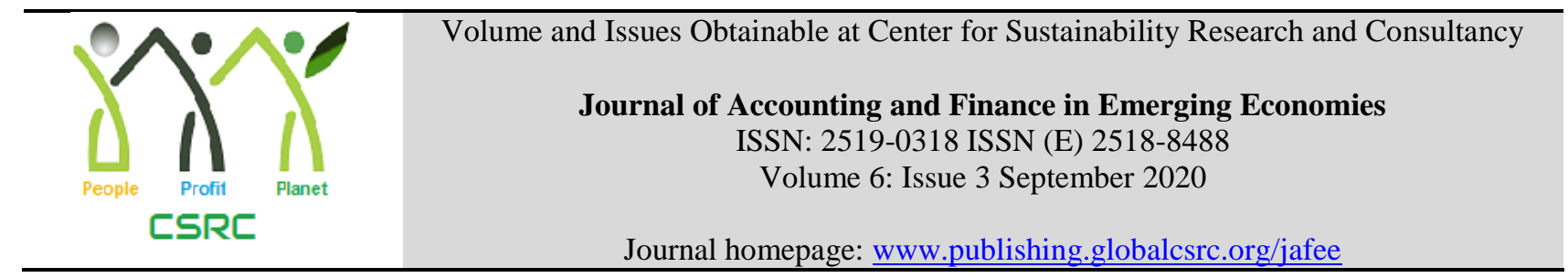

\title{
Privatization of National Assets: Solution to Fiscal Deficits
}

\section{${ }^{1}$ Najma Sadiq, ${ }^{2}$ Ume Laila, ${ }^{3}$ Tahir Mehmood, ${ }^{4}$ Tooba Rehan Haqqi}

${ }^{1}$ Assistant Professor, Head of the Department, Department of Mass Communication, School of Social Sciences and Humanities (S3H), National University of Sciences and Technology (NUST), Islamabad, Pakistan, najma.sadiq@s3h.nust.edu.pk

${ }^{2}$ Assistant Professor, Government \& Public Policy, School of Social Sciences and Humanities (S3H), National University of Sciences and Technology (NUST), Islamabad, Pakistan, dr.umelaila@ s3h.nust.edu.pk

${ }^{3}$ Assistant Professor, Department of Communication studies, Bahauddin Zakariya University, Multan, Pakistan, tahirmahmood@bzu.edu.pk

${ }^{4}$ Graduate Public Administration, Department of Government \& Public Policy, National University of Sciences and Technology (NUST), Islamabad, Pakistan, Tooba.bpa16s3h@s3h.nust.edu.pk

ARTICLE DETAILS

\section{History}

Revised format: August 2020

Available Online: September

2020

\section{Keywords}

Privatization, National Assets,

Fiscal Deficit, Privatization

Pakistan, State Owned

Enterprises, Public Goods,

Public Services

\section{JEL Classification}

H3, $H 6$
ABSTRACT

This paper is exploratory in nature and shall investigate the nature of privatization law keeping in focus the impact this law has created on the fiscal deficits. State Owned Enterprises are the surfeit of a nation which provides those goods and services which the market sometimes is unable to provide. These enterprises have a large share in the macro-economic structure of a county that aims in providing goods and services at a rate that is affordable for everyone. Through this paper the attention of the concerned authorities shall be drawn towards the fact that privatization is not the ultimate solution to all economic problems and that there are numerous other options and choices which will to cater the declining nature of our economy and increase in the heavy debts. This paper also has some factual reasoning regarding the enterprise which have been privatized but are not working up to the mark. Hence the gap in the nature of the policy making must be addressed looking for policies that will revive the working of SOE's. The recommendation proposed in this paper allows foreign investors to invest in the public assets as it would increase the trading between the countries.

\section{OPEN ACCESS}

(C) 2020 The authors, under a Creative Commons Attribution-NonCommercial 4.0

Corresponding author's email address: najma.sadiq@s3h.nust.edu.pk

Recommended citation: Sadiq, N., Laila, U., Mehmood, T. \& Haqqi, T. R. (2020). Privatization of National Assets: Solution to Fiscal Deficits. Journal of Accounting and Finance in Emerging Economies, 6(3), 897-904

\section{Introduction}

Privatization is basically a process of transferring the publically held entities to private owners either by selling the government enterprises or allowing the private individuals and business owners to intervene in the matters of Public Corporations (Pakistan G. o., n.d.). In Pakistan privatization of State owned Enterprises is done in order to reduce the public debt and fiscal deficit. This paper will draw the attention of the concerned authorities towards the fact that handing over the State Owned Enterprises (SOE's) to the private owner's is not the only way to enhance the efficiency and reduce the deficit, as losing the national assets is synonymous to losing the control over public goods. 
In our reasoning, the National Assets must not be privatized as it has an adverse effect of national image on international forum declaring the government to be incapable of performing its duties. It can be seen that the desired outcomes of privatization is not achieved. It was felt that with the selling of enterprises the economy of Pakistan would shift from downfall to the increasing graph. But the outcomes were somewhat different then expected. The only thing the country had achieved since the initiation is the economic, social and political costs.

\subsection{Privatization law}

The most important facet of Privatization Law was to address the cumulative debt and fiscal deficit which are related to the economic costs (Pakistan G. o., n.d.). Low expenditure related to poverty, rising poverty, unemployment, lack of provision of basic necessities, low expenditure on development, and more population driven towards poverty line all shows the social costs that the country had to bear. Last but not the least increased unrest in society, unstable politics of Pakistan, increase in threats to life and property all reflects the political costs. These three were the important facets which the government had aimed to overcome when they had passed the Privatization Act or Privatization Law.

\subsection{Limitations of the Study}

Due to lack of research in this field this research paper faces a large research gap. Not only this due to COVID outbreak we were unable to carry out field research. Some of the results may vary from what the actual situation is.

\section{Research Methodology}

This research is qualitative in nature and employs exploratory approach in reasoning and investigation of the topic. All of the data collected is through the different secondary resources and pertinent websites within Pakistan.

\subsection{Research Question}

This paper shall answer the following question:

- How does privatization of public enterprises help to reduce the fiscal deficit of Pakistan?

\subsection{Research Objective}

This paper has the following objectives:

1. To investigate why Privatization Law was promulgated?

2. To investigate the impact of privatization on investments.

3. To investigate whether privatization helps in reducing the fiscal deficit.

\subsection{Research Hypothesis}

This research shall focus to evaluate the impact privatization of the SOE's are creating to bridge the fiscal gap.

\section{Literature Review}

In European countries it is perceived that privatization is a main pre-requisite for expanding markets, but studies reveal that privatization only leads to the enhanced gaps of fiscal deficits. This trend has been observed in almost all of the European countries where as evidence regarding the fact, privatization increases when fiscal deficit reduces, lacked (Ordh, Walker, \& R. Hunt, 2016). Europe has seen the fastest privatization after 2008 in order to overcome the 2008 financial crunch (Voszka, 2019) Whereas in developing countries privatization is often attributed to the economic efficiency, expansion of internal and external markets, generation of governmental revenues, provision of customer preferred goods and etc., but the case is not the way it appears to be. In developing countries the privatization programs are put forth by the donor agencies and thus in order to acquire funds and loans the requisites of those agencies have to be fulfilled prior to privatization hence the true essence of privatization is always lost creating negative social and political implications (Haque, 2000).

In Pakistan, Privatization came into the light with the motive to reduce government subsidies to public entities and also to enhance the tax revenue generation from the private enterprises. With the rise of this process a total of 166 State owned enterprises were sold out in order to gap the budget deficit of the then acting government but this selling was of no use. In return, the government not only lost control of the SOEs but also failed to bridge the deficit gap (yar, Arif, \& Ab. Rahim, 2013). In order to achieve the privatization objectives at fullest, organizational Development Perspectives must be incorporated into the privatization programs. Using different dimensions of OD interventions, like change of 
planning/ implementation etc. will help the governments to achieve the set objectives of nationalization like reducing fiscal deficits, reducing budgetary costs, enhance organizational efficiency and much more (M. Pheko, 2013).

The privatization policy of Taiwan has seen a lot of setbacks due to numerous flaws it has. Investigation reveals its due relation with the liberalization and democratic policies at the same time (Tom, 2010). Similarly, Sub-Saharan African countries privatize its nationalized assets due to inflation, least focus of government on infrastructure and income disparity. But these factors lack the efficiency and potential to achieve the true essence of denationalization (Adam \& Mengistu, 2008). Due to limited employment opportunities in the public hospitals, a new trend has been observed to privatize the hospital sector in order to reduce unemployment. But through detailed analysis of privatized hospitals of Germany it has been seen that no such employment related effects have been observed (Heimeshoff, Schreyögg, \& Tiemann, 2014). But if the dynamic model of privatization will be adopted financial constrains can be reduced which makes it difficult for the government to finance the fiscal year (Che, 2009).

\section{Research Analysis}

\subsection{Promulgation of Privatization Law}

The idea of privatization or Denationalization program came into existence after the Soviet Union economic collapse during the economic reign of politically elected government of Nawaz Sharif, with the aim to improve GDP and economic conditions of Pakistan. The privatization program was formally launched on January 1991 under the prime minister ship of Mr. Nawaz Sharif, with a vision to promote free market economic principles, attract foreign investment and increase private ownership (Pakistan E. , 2012).

The top down hierarchal structure is maintained with having Board of the Privatization Commission (PC) on the top which decides what radical steps should be taken and what kind of course is suitable to be followed. The course of action is carried on after the approval from the Council of Common Interests. The task of Privatization Commission is restricted to the control of federal assets which are directly overseen by the Government and whose major shareholder is the Public Government. Apart from selling of the shares and assets, it can also offer some sort of rights and concessions to the private parties so that they can operate the publicly owned assets properly and efficiently (Pakistan E.-G. , 2012).

The fully handing over of assets to the private owners is carried out through certain procedure. Initially the noncontrolled share of the company is floated in the market by the management. Such a type is called as "Partial or Limited Privatization". This is not characterized by the complete transference of powers from the management into the hands of third party. Through the results it has been observed that "partial privatization" has little to no effect therefore slowly and with the passage of time this partial control shifts to entire control by the private owners.

The workforce in the public sector organizations are very hostile and rigid towards the process of privatization. Back in 2005 a protest was staged by the PTCL workers on the passage of the resolution that the state corporation will be handed over to private owners by the then Prime Minister Shaukat Aziz. Despite the serious demonstrations the government did not paid any sort of attention over the unrest, and the bill was passed. This had resulted in workers' losing their jobs and benefits. The reason behind the stubbornness of public servants is because the governmental jobs are one of the prestigious jobs having a bunch of perks and benefits. Not only that the employees have less workload and per week hours' work is evenly distributed. The firms do not demand any sort of extra work or overtime from their employees. On the other hand, the privately-owned firms have their prescribed rules and regulations with predetermined workloads which do not have any concession.

Many of the state-owned entities have been approved to be privatized. Some of them include OGDCL, Mari Petroleum, Pakistan State Oil, Sui Sothern Gas, Sui Northern Gas, Habib Bank, United Bank, National Bank of Pakistan, State Life Insurance, Pakistan Steels Mills and many more to be named. But the fact remains the same this $100 \%$ transfer of shares of most of the entities still have not paved the way for any government to boost up the economy of the country. The country is still lagging behind the target and is facing serious economic recession along with increased inflation and devaluation of money. 


\subsection{Privatization Law and Investments}

The Privatization Law says that $90 \%$ of the money recovery from the privatization is compulsory to be utilized in debt sequestration. As stated in The Fiscal Responsibility and Debt Limitation (FRDL) Act, the outstanding public debt must not surpass by $60 \%$ in the total GDP. From the statistics it has been observed that only during the period of 2006-2011 the public debt was controlled and was under $60 \%$. It was not achieved wholly solely with the precedence of Privatization but it was achieved due to debt deferment and reform. In the period of two PML-N governments the debt had reached a high mark of 104\% back in 1990's. During 2003-2007 the privatization money was treated as nontax revenue receipts which is the only reason why the fiscal debt was 2.3-4.1\%. Apart from this period, it was extremely high. The following table will show the basic relation between the socio-economic costs at the very initial stages of this law (Asian Development Bank, 1998).

\begin{tabular}{|l|l|l|l|l|l|l|}
\hline YEAR & $\begin{array}{l}\text { PUBLIC } \\
\text { DEBT }\end{array}$ & $\begin{array}{l}\text { FISCAL } \\
\text { DEFICIT }\end{array}$ & $\begin{array}{l}\text { TOTAL } \\
\text { INVESTMENT }\end{array}$ & $\begin{array}{l}\text { POVERTY } \\
\text { RELATED } \\
\text { DEVELOP. }\end{array}$ & $\begin{array}{l}\text { DEVELOP. } \\
\text { EXP. }\end{array}$ & $\begin{array}{l}\text { \% } \\
\text { POPULATION } \\
\text { BELOW } \\
\text { POVERTY }\end{array}$ \\
\hline $\mathbf{1 9 8 7}$ & - & - & 26 & - & - & - \\
\hline $\mathbf{1 9 8 8}$ & - & 9.0 & 21 & - & 7.0 & 29.2 \\
\hline $\mathbf{1 9 8 9}$ & - & 7.0 & 21 & - & 6.0 & - \\
\hline $\mathbf{1 9 9 0}$ & 91.5 & 7.0 & 22 & - & 7.0 & - \\
\hline $\mathbf{1 9 9 1}$ & - & 8.8 & 26 & - & 6.4 & 26.1 \\
\hline $\mathbf{1 9 9 2}$ & - & 7.5 & 25 & - & 7.6 & - \\
\hline $\mathbf{1 9 9 3}$ & - & 8.1 & 20 & - & 5.7 & 26.1 \\
\hline $\mathbf{1 9 9 4}$ & - & 5.9 & 20 & - & 4.6 & 28.7 \\
\hline
\end{tabular}

From the above table it is inevitable that, Investment which is the most powerful economic driven tool is on decline due to this deregulation and privatization. With a high investment of $26 \%$ of GDP pre-privatization in 1987 it has crumbled to $20 \%$ in 1994 and with much deterring nature has fall down till 14\% in 2013-14. In reality, it is thought that on freeing the public resources from loss-incurring SOE's the left one would be used in social sector and human development. But it is evident from the table that development expenditure has declined from as high as $7 \%$ in the 1988 to $4 \%$ of total GDP in 2014 (Bank, 2014 ).

Apart from other things, the privatization has increased the prices due to which more parties are attracted into the private sector thus inviting the serious competition. An investigation conducted back in 1990's which clearly showed that the prices of the privately producing goods had enlarged; despite the expectation of reducing it (A.R. \& A.R, 1997, Winters). The daily life products in consumer basket and the basic capital of production were overpriced which eventually increased the consumer price index. The Whole Sale Price Index was even higher, as shown in another study, which showed its bigger contribution to general upsurge (Akhter Hassan, 2012 ).

Switching the context from social costs to political costs, the autonomy still vested into the hands of the elites. Despite it was aimed at taking important decisions which might be effective in the betterment of workforce as well as the general public. But the fiscal policy was made only to bridge the competing interests of the elites. This privatization was nothing but only the change of powers of "assets for the private parties by the private parties". Hence it can be concluded that there was no reduction in the top-brass over-powering the workers' interests and simultaneously this privatization law was unable to attract foreign and internal investments as promised.

\subsection{Privatization and Fiscal Deficits}

Privatization does not enhance efficiency or competition. The major concern should be shifted over to the regulatory bodies which should work hard in order to satisfy consumers' rights without harming the investments. Privatization often leads to cartelization, a condition in which firms join hand together in order to pursue their interests and demands; this is worst condition then the public monopolies. Therefore, it has neither reduced the public debt, nor has it improved a kind of financial condition. 
Recently it can be seen that that the national flag carrier of Pakistan, which is Pakistan International Airline has been targeted to be denationalized. It is one of the major asset and the only left flag carrier of Pakistan which is a source of dignity and picturing of our country on the international medium. The reason given behind this act is that past many decades the national flag carrier is experiencing losses and it has become a huge liability on the state pal, therefore ever government has the first priority of ridding national airline. The net loss that the airline had faced in 2017 was Rs 325 billion. It is claimed that by selling the enterprise it will not be beneficial for the people but also for the country and the travelers as they will be having high quality services and flexible rates. The concerned authorities have reported that due to the losses it had impacted on the country with a total of 600 billion in the past three decades.

It has been seen that every time public government is unable to provide capitals to an enterprise or it is undergoing any sort of economic pressure it decides to sell-off the national asset just to acquire some financial funds. But it must also be noted that these monetary funds are not being used to overcome the deficits but they are only being used for either paying-off the salaries of governmental officers or being used for the things which have significantly low importance in the growth and development of the country and economy.

The major work of the government is to provide public goods to the population and once it fails to do so it cannot compel the private sector to provide the goods as both the sectors are opposite in nature; private sector tantamount to profit making whereas public sector synonymous to welfare making. Privatization is not that glossy as it appears to be. It cannot turn around the state of government entities or the economy of Pakistan. From the past experience it has been observed that the public corporations used to provide the goods at a very low market prices as compared to the private enterprises. Not only is that loss of billions of rupees also incurred by the national exchequer due to non-submission of revenues. . From the following examples the point of investigation can be defended and explained.

I. OGDCL; during the fiscal year 2014-15 it generated a total profit of PKR 91 Billion and provided fuel and gas at a price 40-50\% lower than the private sector (OGDCL, 2014-15).

II. PSO; which generated the after-tax net profit of around PKR 125,558,000,000 and was added to the end of fiscal year on $30^{\text {th }}$ June 2013; which was an increase of 39\% revenue generation from the previous year (PSO, 2013).

III. PTCL; during the regime of Musharraf control of PTCL was given to Etisalat, a Public Sector Enterprise of UAE, in which all the shares of PTCL were given to a minority shareholder and an agreement was made that the sum will be paid in installments. The iconic fact is that the proponents of privatization say that the state cannot run its vital functions but they do not care that they have given the enterprise in the hands of foreign public entity. To analyze how successful this scheme was we can realize the fact that the same firm which was generating billions of net profit is now incurring heavy losses despite increased charges and a drop in standard and quality of customer services (PTCL, 2015).

IV. KESC; again, was sold to a private party with the hopes that it would enhance its performance, but it has become a liability on government which is on and off rescued from being drown in debts. The failure of private owners to invest in infrastructure has led to the shortfall in electricity storage and ultimately increased the load-shedding (K-Electric, n.d.).

From the above examples it can be concluded that the government of Pakistan has only faced losses in the shape of low revenues and falling share prices which has ultimately resulted in the sufferings of public with deteriorating services and high prices of commodities. Hence in a nutshell, by handing over the services provision to any other party only averts the claims and grievances regarding the public organizations it does not enhance the production, provision, efficiency or economy.

\section{Recommendations}

In response to the proposed hypothesis, the failure and inappropriate working of enterprises cannot be attributed to denationalization of those assets just to make them as profit-making institutions with low efficiency and effectiveness along with diminished services at a higher rate. As for those entities like PIA which are incurring the losses since last 10 years, those policy options must be taken into account which will not only benefit the National Asset but will also be helpful for the country on a whole. Following are some of the policy alternatives: 


\subsection{Decentralization of the Enterprise}

The elite management and top-down hierarchal structure must be abolished and the decision making power must go down till the grassroots levels. More public administrators must be inducted so that they coach and guide the labor force towards what decisions are right and what are wrong and what are best in the interest of the corporation. The state must open up the entity for the civil societies to intervene and help the government to take best course of action.

Pros: in this way the state will be able to attain better accessibility, more power over decision-making, empowerment over the expertise, and comfortable relationship between the labor force and management which will enhance the efficiency and working of the employees.

Cons: the decentralization might increase the lack of consistency of workers due to low scrutiny, involvement of personal connections for more benefits, and might take time for the management to accept the radical change.

\subsection{Unions to be Established}

Unions are often established that not only pursue the demands of the workforce to the management but also unite together to take decisions which will be best in the interest of the corporation. In public organizations, unions must be created by law so that both the management and labor force align their goals and objective with that of organization along with no submission of individual rights. Not only had that unions also set a standard below which no labors accepted.

Pros: The union, and not the employer, has to maintain the discipline of workers with the legal right that it can terminate the labor who is not abiding by. This enhances the working scrutiny of labor force. Not only that they have power to provide better wages, improved benefits and enhanced working of the labors which will more or less be helpful in enhancing the efficiency and productivity of corporation.

Cons: this might increase the tension between the employees and the employer resulting in the hostility of nature in the organization. Resultantly it will welcome the cascade of galvanized strikes by the labor force.

\subsection{Inviting the expertise of knowledge in the management}

The government must have an open invitation for the expertise in the knowledge of management and public dealing. It must encourage their involvement in the management, finance other departments so that they can oversee and direct the course of actions along with motivating the employees by an incentive pay plan that if they work efficiently, produce large quantity at low rates and work for the betterment of the country they will be rewarded for that.

Pros: the new generation has increased knowledge of sharing and collaboration. They share information with no hesitation just as an open software shares. This will enhance the sharing of expertise information which will eventually produce more skilled and professional workforce.

Cons: the thumb rules management and administration style will adhere to this concept of outside intervention. They will not be ready to allow any third person to interfere in their style of dealing. This might eventually create a disturbance resulting in third party to quit.

\subsection{Involvement of International Collaboration}

There is a vast variety of researchers globally who are willing to share their experiences, their information and abilities with the underdeveloped countries' governments in order to enhance their working capability and guide them towards the ways in which they are able to reduce their fiscal debt and boost up their economy. They will also introduce competitiveness and innovation and will produce goods and services according to international standards.

Pros: the goods and services produced according to the international standards will have a major share in international markets also. This will increase the exports of the country with increased balance of trade and will finally be adding a lot of monetary funds in our capital and current account thus reducing our fiscal deficit. Secondly, the general public will also be interested in buying high quality products thus the demand for goods produced by the government at high quality and low rates will increase eventually adding to the revenue generation.

Cons: the problem in adopting this policy will be that of the difference in the governing practices of our country. Our government is a mixture of dictatorship and democracy with much involvement of external forces. The differences in the government practices will adhere to achieve the desired goals. 


\subsection{Encouraging Foreign Investment}

Foreign investment in the public entities will enhance the working capability of the enterprise. It is characterized by the involvement of the foreign investors in the management role as the shareholders with no control or ownership over the asset. Foreign investment brings in capital flows from the country investing. The increased foreign exchange will fill the gap between domestic savings and expenditure. Not only will that it be helpful in raising our economy and reducing budget deficits.

Pros: with the advent of foreign investment Pakistan will be able to provide more job opportunities to its people, the balance of payments will be more favorable, followed by technology exchange which will enhance the quality and efficient resources will be produced. Hence, with the regional development much funds will be added to the economy. Cons: it might result in the intervention of foreign governments in the domestic affairs of Pakistan. There is a risk that domestic business practices might disrupt allowing foreign investors to gain control over the corporate sector.

\section{Conclusion}

According to my knowledge the most efficient and effective policy will be of allowing foreign investors to invest in the public enterprises. Pakistan is a demographic country with no strict and rigid rules of the business. Foreign investors would happily finance their stake in assets of Pakistan. This is because Pakistan provides an assured freedom of establishment with no binding agreement. The investors would take back their stake any point in time if they are unable to carryon. For the declaration of assets the competent authority of Ministry of Finance and Board of Investment plays its part. This ensures the investors that they will not be held more than what they are liable for. Last but not the least SECP regulates all the investment activities and has separate constitution which tells about the rights and duties of investors.

Apart from the benefits on the part of investors, Pakistan will too benefit from the FI. It will enhance the average yearly income of the country and its populace. Along with this disparity between the revenue generation and cost will also be reduced. By taxing investors we will be able to generate high tax revenues due to high exchange rates. The increased revenues will be added in the budget at the end of the fiscal year which will be used to pay off the debts.

It is often noted that the State Owned Enterprises enjoy a lot of perks and benefits including subsidies and grants and moreover, $80 \%$ of the total bank loans goes into the account of SOE's. The idea of mixed ownership with foreign investors will be a way forward in making the enterprises more efficient and accountable. This will be possible because of the domestic way of treating the foreign stakeholders.

As the reform is inculcating third party ownership, the non-state firms will be encouraged to take part in this reform by buying shares, stakes or bonds from the enterprise and sharing their part of stake for the betterment of a nation. Another reason why this recommendation is considered to be successful is that the state owned corporation will be categorized in two ways; one which will have foreign investors and will be working to make profits and the other which will be providing public goods and welfare. Both the factions will work together and will pave way for more revenue generation and also this will reduce the fiscal deficits.

This will also change the shape of the management style along with more decision-making power distributed among the board of directors and shareholders. Through this an outcome or fiscal and welfare policy shall be drafted which will prove itself best in the working of government for providing public good. This will not alter the status of corporation as being the National Asset but will only alter the style of working along with the elimination of corruption and malpractices.

The investment agreement will be drafting according to the OECD principles so that no threat to national security shall be feared. This agreement will be mutually beneficial and will provide adequate autonomy the state to take its shares back from the investors if they perceive that the investors are not abiding by the pact or if they are trying to take hold of the corporation. One retaliation will be observed from the management as they will not be ready to share their powers with a third party that happens to be a foreign party. They might show rigidity towards the new styles and might not agree upon being accountable. Here the government must intervene and give sufficient knowledge so that they are able to understand what sort of consequences they will have to bear if they do not agree with the stance. 
It can be concluded that outsourcing the national assets is not a way to eliminate inadequacy, shortfall or incompetency. More problems arise when the government sells-off its national asset; the government becomes more corrupt, inefficient and the graph of economy goes down. Not only that levels of accountability and transparency are not maintained, and it drowns deeper into the debts.

\section{References}

A.R., K., \& A.R, K. (1997, Winters). Pakistan's Industrial Experience andd Future Directions. Pakistan Institute of Development Economics .

Adam, S., \& Mengistu, B. (2008). The Political Economy of Privatization in Sub-Saharan Africa. Social Science Quarterly, 78-94.

Akhter Hassan, K. (2012 ). The Impact of privatization in Pakistan . Lahore : Ferozsons .

Asian Development Bank, A. (1998). Impact Analysis of Privatization in Pakistan . Manila .

Bank, W. (2014 ). World Development Indicators 2014. Retrieved from World Development Indicator: https://openknowledge.worldbank.org/handle/10986/18237

Che, J. (2009). A Dynamic Model of Privatization with Endogenous Post-Privatization Performance. The Review of Economic Studies, 563-596.

Chowdhury, F. L. (2006). ' Corrupt Bureaucracy and Privatisation of Tax Enforcement'.

Haque, M. S. (2000). Privatization in Developing Countries: Formal Causes, Critical Reasons and Adverse Affects . In A. Farazmand, Privatization or Public Enterprise Reform? (pp. 217-238). Westport : Igreenwood Press .

Heimeshoff, M., Schreyögg, J., \& Tiemann, O. (2014). Employment effects of hospital privatization in Germany. The European Journal of Health Economics, 747-757.

K-Electric. (n.d.). Financial Data . Retrieved from K-electric Investor Relations : https://www.ke.com.pk/investorrelation/financial-data/

M. Pheko, M. (2013). Privatization of Public Enterprises in Emerging Economies: Organizational Development (OD) Perspectives. International Journal of Business and Management.

OGDCL. (2014-15). Complete Annual Report 2014-15 . Retrieved from OGDCL- Publications : https://ogdcl.com/sites/default/files/publication/CompleteAnnualReport201420140924204609262.pdf

Ordh, K., Walker, D. A., \& R. Hunt, C. (2016). Privatization and Fiscal Deficits in European Emerging Markets. Emerging Markets finance and trade , 2585-2594.

Pakistan, E. (2012). History of Privatization Commission . Retrieved from Privatization Comission of Pakistan : http://www.privatisation.gov.pk/about/Progress-in-PC.htm

Pakistan, E.-G. (2012, June 2 ). Privatization Comission. Retrieved from Ministry of Information and mass media broadcasting : http://www.privatisation.gov.pk.com

Pakistan, G. o. (n.d.). Privatization Comission of Pakistan . Retrieved from Policies and Objectives : http://www.privatisation.gov.pk/

PSO. (2013). Financial Reports . Retrieved from PSO Investors https://psopk.com/files/pdf/investors/2013/ar2013_03_financials.pdf

PTCL. (2015). Financials . Retrieved from About PTCL https://ptcl.com.pk/Home/PageDetail?ItemId=375\&linkId=1106

Tom, K. (2010). PRIVATIZATION DEVELOPMENT IN TAIWAN: BACKGROUND AND ISSUES. Public Administration Quarterly, 3-21 .

Voszka, E. (2019). Management in Europe: Nationalizations and Privatizations. In M. Szanyi, Seeking the Best Master: State Ownership in the Varieties of Capitalism (pp. 13-52). Central European University Press.

yar, A., Arif, M., \& Ab. Rahim, R. (2013). Privatization and Fiscal Deficit: a Case Study of Pakistan. Research Journal of Finance and Accounting . 